Japanese and one Turkish author might therefore be expected to offer a new perspective. The book, however, is a translation of one published a few years ago in Japanese and therefore seems more concerned to retell the evolution of ideas of European-American origin than to redress the balance. In these circumstances, it is not surprising that Professor Miyashiro's treatment (in Chapter 3) of themes which are drawn principally from studies of the circum-Pacific orogenic belt (notably the concept of paired metamorphic belts, to which he contributed) has a freshness rather lacking elsewhere.

In general, the stated objective - to provide an introduction to theories of orogeny - seems at once too restrictive and too vague to give the book a satisfactory shape. I find it hard to imagine what kind of reader the authors have in mind. In the opening chapter ("Classical Theories") Şengör homes in on the great masters of Alpine geology, placing tectonics firmly at the centre of the stage. Next, "Theory of Orogeny based on Plate Tectonics" provides a standard exposition of the plate tectonic hypothesis that might fit into any general textbook. The fourth chapter, "Mechanisms of Orogeny", abandons consideration of the development of ideas in favour of a quite advanced treatment of the mechanical properties of plates and the stresses acting on them. The final contribution, on Precambrian orogenies, is little more than perfunctory.

The view from Japan, which might have proved so illuminating, never quite materializes.

Janet $V$. Watson is a Professor of Geology at Imperial College, University of London.

\section{The succession of ecologists in North America}

\section{William Coleman}

\author{
Saving the Prairies: The Life Cycle \\ of the Founding School of \\ American Plant Ecology, \\ 1895-1955. \\ By Ronald C. Tobey. \\ University of California Press: 1982. \\ Pp.315. \$32.50, £21.25.
}

THE PRAIRIES referred to in the title of Ronald Tobey's book were the grasslands of western North America, the saviours the offspring of that peculiar breed of social philosopher, nature enthusiast and aspiring scientist characteristic of the late nineteenth-century United States. Convinced that the prairies could withstand virtually any insult, the founders of American plant ecology discovered to their distress that the great restorative, plant succession leading to a return of the regional climax, could be and in fact had been dramatically disturbed. The double blow of rapid settlement accompanied by wanton exploitation and the Great Drought destroyed a plant-community that had prospered on the middle and high plains for many thousands of years. Lost plant communities were followed by a loss of scientific conviction, hard upon the heels of which was the disruption of the Second World War. After 1945 came the re-creation of plant ecology along new lines, notably based upon the notion of the ecosystem - most cogently expressed by Arthur G. Tansley in England - and upon the emerging principles of productivity ecology.

These several events constitute a somewhat complicated story which Ronald C. Tobey relates in a by no means uncomplicated manner. Several potentially substantial books lurk within this volume and the general sense of busyness is not reduced by the author's keen insistence on what he seems to regard (p.8) as his major innovation, namely, systematic application of citation analysis as a tool for the identification and description of a school of scientific throught. There is a disturbing sense of the obvious, however, in the principal conclusion which Tobey draws from this numerical material - an "enduring determinant of citation behaviour is the intellectual interest of the scientists in the literature"' (p.149).

The "School" in question was that of Nebraska botanists founded by Charles E. Bessey during the 1890 s and soon raised to larger dimensions by a truly exotic bloom, Frederic E. Clements. Clements viewed the botanical formation as the primary unit of ecological analysis; he, his associates and students developed the quadrat technique for studying the species constitution of a formation as a means by which to introduce numerical rigour into the seemingly subjective domain of floristic description. And he adapted the ancient metaphor of the social organism to fit the grassland and other formations, and thus by 1916 had come to insist upon the unidirectional trend of plant succession. If succession under given climatic conditions, such as those encountered in central North America, invariably returns a community to its climax, we need not fear that even serious human disturbance of the region can diminish its recuperative powers.

Unfortunately, the facts suggested another conclusion and it was Clements's foremost student, John Weaver, who made it widely known. The settlers had indeed destroyed the native plant community and the only hope for a region which, with its plant cover gone was also rapidly losing its soil, was for man himself to attempt to restore the original conditions or at least to retard the process of deterioration. Weaver well understood this point and Clements, too, embraced it with enthusiasm even though it shattered the cognitive heart of his programme; the Nebraska school prospered during the 1930 s by providing expertise and training scientists for government-sponsored programmes for prairie rescue, a salvation that now was seen not to reside in the nature of things but to depend upon human intervention. There is a fine moral here for those who rush to apply the latest and seemingly most sound scientific conclusions. The Clements school at different periods entertained conflicting environmental approaches and did so always with the conviction of the purity of its scientific principles. The prairies, however, were unforgiving and the optimistic doctrine of grassland succession and inevitable recovery collapsed only as the prairies themselves were exhausted.

Tobey provides a comprehensive account of the influential Nebraska school from its birth to its demise. His discussion of Tansley, a decisive figure in British ecology and a shrewd critic whose social and political views were as significant for his scientific work as were those of Clements for his outlook on ecology, is outstanding. Nebraska's early rival, the Chicago school of ecology led by Henry Chandler Cowles, working out the programme of Eugenius Warming, receives notice but, unfortunately, little close scrutiny. The whole domain of autecology is not discussed. These limitations may indeed reflect historical reality: perhaps the Clementsian successionist programme did serve to establish the "founding school of American plant ecology". But rivals also existed and the reasons why their views did not prosper remain unclear. Certainly Tobey's claim that the triumph of the Nebraskans is to be explained "sociologically" (that is, by the successful creation of a large-scale research and training programme, a distinctive feature of the aggressive new American land-grant universities), is part of the answer. And so, too, is the optimism that informed the early fancies of Frederic Clements regarding the wonderful evervivifying garden in the American west. These, however, are still but incomplete answers and they necessarily return and confine attention to Nebraska.

Within that framework, Tobey has prepared a valuable introduction to the general theme of the formation and transformation of disciplines in the natural sciences, and to the interrelated issues of ecological understanding and environmentalist action (really, for long years, non-action). Saving the Prairies should be widely read and, more importantly, its suggestions extended and silences explored.

William Coleman, currently Research Fellow at the Zentrum fü interdisziplindre Forschung der Universitat Bielefeld, is Professor of History of Science and History of Medicine at the University of Wisconsin, Madison. 